Farid Al Rasyid, Fitri Eriyanti| Faktor-faktor yang Mempengaruhi Partisipasi Nelayan dalam Program Asuransi Nelayan di Kabupaten Pesisir Selatan

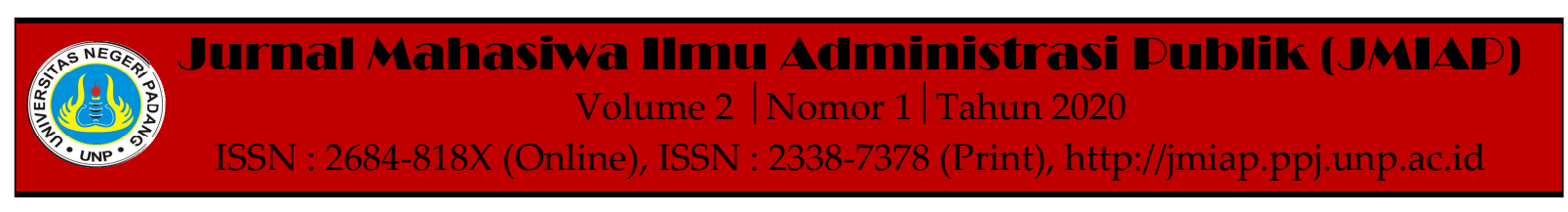

\title{
FAKTOR-FAKTOR YANG MEMPENGARUHI PARTISIPASI NELAYAN DALAM PROGRAM ASURANSI NELAYAN DI KABUPATEN PESISIR SELATAN
}

\author{
Farid Al Rasyid ${ }^{1(a)}$, Fitri Eriyanti' ${ }^{2(b)}$ \\ ${ }^{1}$ Jurusan Ilmu Administrasi Negara, Universitas Negeri Padang \\ ${ }^{2}$ Jurusan Ilmu Administrasi Negara, Universitas Negeri Padang \\ a)faridalrasyid10@gmail.com, b)fitri.eriyanti@fis.unp.ac.id
}

\begin{abstract}
This research is about program to increase fisherman's participation in an insurance program in Pesisir Selatan Regency. The research objective of this research is to study and analyze the factors that influence participation in a fisherman insurance program in Pesisir Sekatan Regency. Thus research was conducted on fisherman who discussed in the fisherman in insurance program using purposive sampling methods, data collection and observation, interviews and documentation studies, informant research consisting of the Dinas Perikanan Pesisir Selatan Regency and fisherman who sought fisheries insurance. The result of the study describe the factors of fisherman's participation in the insurance program, namely knowledge and expertise, level of education, and beliefin certain cultures and found to be related to fisherman's participation in this program is very low and collided with factors of belief in norm so as to minimize participation in this program.
\end{abstract}

Keywords : Empowerment, Fisherman's Participation, Fisherman's Insurance

Corresponding author.Email.faridalrasyid@gmail.com, fitri.eriyanti@fis.unp.ac.id

How to cite this article. Rasyid, F. A \& Eriyanti, F. (2020). Faktor-faktor yang Mempengaruhi Partisipasi Nelayan dalam Program Asuransi Nelayan di Kabupaten Pesisir Selatan. Jurnal Mahasiwa Ilmu Administrasi Publik (JMIAP) Jurusan Ilmu Administrasi Negara Fakultas Ilmu Sosial Universitas Negeri Padang, Volume 2 (1), Hal. 51-56.

http://jmiap.ppj.unp.ac.id

ISSN : 2684-818X (Online), ISSN : 2338-7378 (Print)

Copyright $\bigcirc 2020$. Published by Pusat Kajian-Pemberdayaan dan Pelayanan Masyarakat (PK-P2M) FIS UNP Padang 


\section{PENDAHULUAN}

Nelayan termasuk warga yang memiliki ekonomi yang rendah berbanding terbalik dengan jasanya sebagai salah satu pahlawan pertimbangan, Dan ini menjadi suatu pertanyaan yang mendasar kenapa mereka miskin atau apakah mereka menjadi nelayan karena miskin atau sebaliknya,sementara kondisi sumber daya laut yang melimpah menjadi salah satu masalah kemiskinan (Ahmad, 2012:16). Sehingga fenomena ini membuat bahwa kekayaan alam sering menggerakkan mata kita semua dalam hal terciptanya ketergantungan dan kepasrahan terhadap sumber daya alam yang ada sehingga mengakibatkan tidak berkembangnya kualitas sumber daya manusia.

Ternyata banyak faktor yang menjadi permasalahan nelayan untuk menghambat kesejahteraan umum yang membuat mereka terperangkap di jurang kemiskinan, salah satunya menurut Adam (2015:146) menegaskan bahwa online itu sangat identik dengan kondisi ketidakberdayaan mereka salah satunya adalah risiko ketidakpastian sangat besar khususnya pada perubahan lingkungan.

Faktor iklim inilah yang membuat pekerjaan sebagai seorang nelayan itu mempunyai resiko yang amat tinggi sehingga dapat mengancam nyawa dan masa depan keluarga nelayan dalam pekerjaan menangkap ikan di lautan.selamatan lain merupakan pokok utama yang harus menjadi perhatian kita bersama atau peran pemerintah yang menjamin keselamatan masyarakat nelayan tersebut.

Upaya pemerintah pun sudah tertuang pada aspek yuridis dengan membuat UU 7 tahun 2016 yang berisikan perlindungan dan pemberdayaan nelayan pembudidaya ikan dan petambak garam pada bab 1 pasal 29 dan pasal 31 menjelaskan asuransi perikanan merupakan upaya pemerintah dalam menjamin jiwa serta pertanggungan risiko nelayan diberikan perjanjian akan memenuhi kewajiban serta finansial dengan mitra perusahaan pemerintah.
Realitanya sangat miris sekali ketika program asuransi nelayan yang merupakan perwujudan upaya pemerintah dalam memenuhi hak nelayan untuk mendapatkan perlindungan dan jaminan atas jiwa mereka dan akan membantu nelayan maupun keluarga neraka tidak berada pada posisi yang lebih tinggi dan realita terburuknya dalam aspek empiris dalam persilatan yang berjumlah 1884 jiwa dan yang terdaftar mengikuti program asuransi nelayan hanya 916 jiwa,ini menunjukkan bahwa program ini tidak berjalan dengan yang diharapkan dengan minimnya partisipasi itu sendiri.

Realita yang perlu diperhatikan dengan melihat pada aspek kesenjangan keikutsertaan nelayan pada program asuransi nelayan dengan jumlah nelayan yang ada di Kabupaten Pesisir Selatan,penulis tertarik untuk mendalami faktor-faktor yang mempengaruhi partisipasi nelayan dalam program asuransi nelayan di kabupaten Pesisir Selatan.

\section{TINJAUAN PUSTAKA}

\section{Partisipasi Nelayan}

Rahayu dan juwono (2019: 168) konseptualisasi komposisi masyarakat sebagai proses langsung dan otentik yang melibatkan individual dan menyatakan dalam sebuah pemerintah untuk memberikan kontribusi secara substantif ke berbagai tahap proses kebijakan misalnya perencanaan dan implementasi.

Warren (2009: 21) dalam Rahayu dan Juwono (2019:174)kepentingan partisipasi dijelaskan di mana lokasi diperlukan sebagai masyarakat untuk dapat memastikan bahwa kepentingan dan nilai mereka diwakili dengan sungguh-sungguh.

Partisipasi suatu masyarakat merupakan pemilihan sikap berani keikutsertaan dari individu dalam suatu organisasi sehingga dapat mendorong individu tadi untuk ikut serta dalam pemenuhan atau pun mencapai tujuan organisasi serta mendapatkan bagian setiap pertanggungjawaban secara bersamasama (Ishak, dkk, 2016:69).

Dari paparan tersebut bermuara pada penjelasan partisipasi merupakan proses 
yang melibatkan masyarakat sebagai organisasi ataupun secara individu dalam sebuah pemerintah untuk memberikan kontribusi dalam proses pembuatan kebijakan perencanaan ataupun pelaksanaan kebijakan untuk kepentingan masyarakat agar kepentingan dan nilai mereka diwakil dari kebijakan tersebut.

Plumer dalam Yulianti (2012:10) ada faktor-faktor yang akan mempengaruhi suatu masyarakat ikut serta atau berpartisipasi sebagai berikut:

a) Pengetahuan dan keahlian

Dasar dari pemikiran masyarakat yang dimiliki akan berdampak kepada seluruh lingkungannya. batas kemampuan dan pemikiran masyarakat tersebut mereka dapat mengetahui proses proses dari suatu program yang ada agar mereka dapat berpartisipasi.

\section{b) Pekerjaan masyarakat.}

Jenis pekerjaan suatu masyarakat akan mempengaruhi cara pandang suatu kelompok kerja, gimana ini akan menjadi hal dasar bagi masyarakat dalam rangka ikut serta dalam suatu program karena berbagai hal yang berbeda dan perbedaan kepentingan.

\section{c) Tingkat pendidikan}

Ini sangat memiliki andil yang besar dan berdampak kepada keinginan dari suatu masyarakat untuk ikut serta karena akan mempengaruhi cara pandang masyarakat untuk melihat program yang akan dijalankan.

\section{d) Jenis kelamin}

Merupakan hal yang cukup mendasar dari sebuah keikutsertaan dari suatu program karena keinginan ataupun kemampuan dari masyarakat untuk ikut serta akan anne-marie dari jenis kelaminnya karena akan mempengaruhi persepsi yang berbeda dari suatu permasalahan

e) Kepercayaan terhadap budaya tertentu Masyarakat sosial masyarakat yang memiliki dasar-dasar normal ataupun budaya yang mengikat yang lahir dan mengakar di tubuh masyarakat tersebut, ini akan mempengaruhi tindakan dan perilaku masyarakat tersebut dalam melihat memandang dari suatu program yang mereka ikut berpartisipasi.

Jadi partisipasi lain itu merupakan pilihan dari tindakan dari keikutsertaan lain ataupun masyarakat nelayan dalam bentuk komunitas atau bentuk yang lain yang mengajak orang lain untuk ambil peran dalam mencapai tujuan kelompok lain serta pengambilan tanggung jawab.

\section{Pemberdayaan Masyarakat}

Menurut Noor (2011: 88) pemberdayaan masyarakat adalah suatu yang dilakukan pemerintah untuk memberikan suatu fasilitas kepada masyarakat dengan merencanakan memutuskan serta mengelola sumber daya yang dimana akhirnya mereka mendapatkan suatu kemampuan dan kemandirian secara ekonomi sosial secara berkesinambungan.

Menurut Andreas dan Safitri (2016: 25) menjelaskan bahwa pemberdayaan diartikan sebagai upaya untuk menerapkan suatu potensi yang sudah ada pada tubuh masyarakat.

Menurut Suhendra (2006: 74-75) pemberdayaan masyarakat adalah suatu proses yang berkelanjutan yang mendorong keterlibatan dari semua aspek atas potensipotensi yang dimiliki oleh masyarakat dimana akan mendorong untuk terbentuknya suatu masyarakat yang Madani yang penuh keseimbangan hak dan kewajiban.

Jadi dari paparan di atas muara pengertian dari pemberdayaan masyarakat merupakan suatu paya untuk meningkatkan harkat dan martabat dari masyarakat serta untuk memanfaatkan suatu potensi yang dimiliki masyarakat untuk melepaskan diri dari kemiskinan dan keterbelakangan.

\section{Asuransi Nelayan}

Menurut Rani (2016:5) pengertian nasionalisme merupakan suatu perusahaan yang dijalankan dengan mengumpulkan dana dari nasabah dengan dinamakan premi 
sebagai imbalan perusahaan akan memberikan pembayaran ganti rugi apabila terjadi peristiwa yang merugikan bagi nasabah secara material untuk immaterial.

Hal ini telah diperjuangkan oleh pemerintah pada aspek yuridis yaitu UU No 7 pada tahun 2016 yang berisikan tentang penjaminan hasil nelayan dimana akan pemenuhan kewajiban finansial dengan mitra perusahaan dan pemerintahan.

Program kementerian kelautan dan perikanan yang sudah menganalisis bahwa sangat diperlukan perlindungan atas nelayan yang memiliki risiko pekerjaan yang tinggi maka kementerian bekerjasama dengan PT asuransi jasa Indonesia (JASINDO) untuk pemberian bantuan premi asuransi bagi nelayan (BPAN) foto nelayan yang memiliki kriteria (Sumbet:www.kkp.go.id).

\section{METODE PENELITIAN}

Dalam melakukan penelitian peneliti memakai pendekatan kualitatif dengan menggunakan metode deskriptif yang lokasi penelitiannya di kabupaten Pesisir Selatan, kecamatan koto XI Tarusan. Purposive sampling peneliti gunakan untuk pengambilan informan dalam penelitian. Data yang dikumpulkan dengan cara pengamatan, wawancara, dan pengambilan dokumentasi. Teknik triangulasi sumber dan metode peneliti digunakan untuk menguji keabsahan data.

\section{HASIL DAN PEMBAHASAN}

Program asuransi nelayan merupakan program pemerintah yang dijalankan oleh kementerian kelautan dan perikanan sesuai amanat undang-undang,berkaitan dengan faktor-faktor yang mempengaruhi partisipasi nelayan dalam program asuransi nelayan dilihat dari tolok ukur yang dikemukakan oleh Plumer yaitu pengetahuan dan keahlian, tingkat pendidikan dan kepercayaan terhadap budaya tertentu.

\section{Pengetahuan dan Keahlian Dasar}

Partisipasi nelayan dapat diukur dari pengetahuan dan keahlian dari nelayan itu sendiri.berdasarkan penelitian yang telah dilakukan oleh peneliti dan amati bahwa partisipasi rangkaian dalam program asuransi nelayan sebagai penjamin keselamatan nelayan dalam menjalankan aktivitasnya terlihat mereka sangat mengetahui tentang resiko dan ancaman keselamatan jiwa mereka dalam bekerja yang sangat tinggi dan lain juga mengerti tahap-tahap dari proses pendaftaran pada program asuransi nelayan ini, hal ini sesuai dengan yang disampaikan oleh lumer di mana mereka mengetahui proses ataupun tahap-tahap dari sesuatu yang akan dilakukan.

\section{Tingkat Pendidikan}

Plumer menyatakan bahwa tingkat pendidikan berpengaruh pada keinginan mereka dalam ikut serta pada suatu program.berdasarkan hasil penelitian yang telah penulis analisis ditemukan bahwa tingkat pendidikan dapat mayoritas tamatan SMP disini terlihat bahwa pendidikan nelayan di kabupaten Pesisir Selatan tergolong menengah dan ini pun juga yang mempengaruhi cara berpikir nelayan pada program asuransi nelayan ini.

\section{Kepercayaan Terhadap Budaya Tertentu}

Plumer menyatakan bahwa segala sesuatu tindakan yang dilakukan oleh masyarakat itu didasari pada budaya ataupun norma yang dipatuhi.berdasarkan penelitian penulis faktor besar yang menjadi penghambat dari program asuransi nelayan ini terapkan di kabupaten Pesisir Selatanditunjukkan pada temuan penulis bahwa mayoritas nelayan di kabupaten Pesisir Selatan beragama Islam dan dari hasil pengamatan dan wawancara penulis dengan nelayan,mayoritas menganggap asuransi sebagai hal yang bertentangan dengan agama Islam karena terdapat unsur gharar, riba, maisir nelayan sebagai pemeluk Islam yang patuh kepada ajaran Islam yang berpegang pada $\mathrm{Al}-Q u r$ 'an dan hadist sehingga nelayan tidak membutuhkan asuransi nelayan dan lebih 
mementingkan kepentingan yang lain untuk menggunakan uang mereka.

Pada penelitian ini penulis menemukan suatu hal yang menjadi pendorong nelayan dalam ikut asuransi yaitu dilihat dari jumlah nelayan di kabupaten Pesisir Selatan 18848 jiwa dan yang ikut asuransi hanya 916 jiwa dari hasil wawancara peneliti mayoritas nelayan yang ikut asuransi adalah penerima BPAN itu bantuan premi selama setahun, ini menunjukkan bahwa cahaya yang mendaftarkan dirinya pada asuransi karena mendapatkan bantuan untuk membayarkan premi dan setelah tahun berikut nilai-nilai yang tidak mendaftar haji karena BPAN hanya satu tahun di bantu oleh pemerintah,ini membenarkan bahwa faktor kepercayaan terhadap budaya tertentu menjadi faktor yang kuat untuk melihat apakah budaya sesuai dengan program yang ditawarkan ataupun sebaliknya program bertentangan dengan budaya yang berkembang di masyarakat nelayan.

Solusi dalam penelitian ini pemerintah harus mengkaji ulang program asuransi nelayan karena ini terlihat dari temuan peneliti atas ketidak ikut sertaan nelayan dalam program dikarenakan bertentangan dengan kepercayaan dan norma yang berlaku sehingga penerapan program guna melindungi keselamatan jiwa nelayan setidaknya dapat dioptimalkan dari kelompok nelayan tersebut dengan kegiatan ataupun program menabung bersama dengan kelompok dimana ketika terjadi sesuatu ataupun bencana dan kemalangan ini akan menjadi aset keluarga nelayan untuk melanjutkan hidupnya.

\section{PENUTUP}

Berdasarkan hasil dari temuan dan analisis dari peneliti yang telah dijelaskan maka peneliti menarik kesimpulan bahwa faktor-faktor yang mempengaruhi dari partisipasi nelayan atas program asuransi nelayan adalah pengetahuan tingkat pendidikan dan kepercayaan terhadap budaya tertentu, faktor faktor inilah yang akan dilihat dari takaran bagaimana suatu masyarakat berpartisipasi ataupun menjadi faktor penghambat jika dari 3 faktor tersebut tidak tercapai ataupun rendah dalam penelitian ini partisipasi nelayan dalam program asuransi nelayan berdasarkan temuan nelayan tidak berpartisipasi atas keinginan mereka sendiri dikarenakan mereka ikut program asuransi karena diberikan bantuan premi dan juga tidak menerima bantuan premi maka nelayan tidak mau mendaftarkan dirinya karena masih menganggap asuransi sebagai hal yang bertentangan dengan budaya dan norma mereka.

Berdasarkan hasil temuan dan kesimpulan peneliti menarik saran itu pemerintah harus mengkaji ulang program asuransi nelayan dan sebagai bentuk antisipasi terhadap keselamatan jiwa nelayan pemerintah ataupun dinas-dinas terkait mengoptimalkan kelompok nelayan sebagai sarana untuk menabung bagi nelayan untuk menghadapi sesuatu yang tidak bisa di ramalkan atau akan terjadi bencana ataupun kemalangan sehingga tabungan tersebut akan menjadi aset bagi keluarga yang lain di masa yang akan datang.

\section{DAFTAR KEPUSTAKAAN}

Adam, L, 2015, Telaah Kebijakan Perlindungan Nelayan Dan Pembudidayaan Ikan di Indonesia. Jurnal Selat, 22(2), 145-162.

Ahmadi, R. 2012. Pemberdayaan Masyarakat Miskin, Jurnal Administrasi Publik, 10(2), 16-31.

Andeas, \& Savitri, E. 2016. Peran Pemberdayaan Ekonomi Masyarakat Pesisir dan Modal Sosial dalam Meningkatkan Kesejahteraan di Kabupaten Meranti dan Rokan Hilir. Pekanbaru: Universitas Riau.

Ishak, F., Roatin, \& Nusantara, A. W. 2016. Analisis Partisipasi Masyarakat Dalam Menunjang Pembangunan Desa di Kecamatan Tonaguna Kabupaten 
Farid Al Rasyid, Fitri Eriyanti| Faktor-faktor yang Mempengaruhi Partisipasi Nelayan dalam Program Asuransi Nelayan di Kabupaten Pesisir Selatan

Konawe. Jurnal Ekonomi, 1(1), 67-79.

Noor, M, 2011. Pemberdayaan Masyarakat. Jurnal I Ilmiah CIVIS, Volume I(No 2).

Rahayu, A. Y., \& Juwono, V. 2019 Birokrasi dan Governance. Depok: PT RajaGrafindo Persada.

Suhendra. 2006. Peranan Birokrasi dalam Pemberdayaan Masyarakat. Bandung: Alfabeta.

Undang- Undang No 7 Tahun 2016

www.kkp.go.id

Yulianti, Yoni. 2012. Analisis Partisipasi Masyarakat dalam Pelaksanaan Program Nasional Pemberfayaan Masyarakat (PNPM) Mandiri Perkotaan. Padang: Universitas Andalas. 